See discussions, stats, and author profiles for this publication at: https://www.researchgate.net/publication/343681321

\title{
Impact of (SARS-CoV-2) COVID-19 on the Five Main Indigenous Language- Speaking Areas in Veracruz Mexico: The Case of the Totonacapan Area
}

Article in SSRN Electronic Journal · January 2020

DOI: $10.2139 / \mathrm{ssn} .3672636$

CITATIONS

READ

0

1

2 authors:

Carlos Medel-Ramírez

Universidad Veracruzana

56 PUBLICATIONS 31 CITATIONS

SEE PROFILE

Hilario Medel-López

Universidad Veracruzana

42 PUBLICATIONS 26 CITATIONS

SEE PROFILE

Some of the authors of this publication are also working on these related projects:

Censos y conteos de población y vivienda, 1895 -2010. Estados Unidos Mexicanos, por Entidades Federativas View project

Vision of sustainability and justice in the town of Totonacapan: The philosophy of lightning children View project 


\title{
Impact of (SARS-CoV-2) COVID 19 on the five main indigenous language-speaking areas in Veracruz Mexico: The case of the Totonacapan area
}

\section{Authors}

Carlos Medel-Ramírez ${ }^{1}$, Hilario Medel-López²

\section{Affiliations}

1. Universidad Veracruzana / Instituto de Investigaciones y Estudios Superiores Económicos y Sociales

2. Universidad Veracruzana / Instituto de Antropología

\section{Corresponding author}

Carlos Medel-Ramírez ( cmedel@uv.mx )

\begin{abstract}
The importance of the working document is that it allows the analysis of the information and the status of cases associated with (SARS-CoV-2) COVID-19 as open data at the municipal, state and national level, with a daily record of patients, according to a age, sex, comorbidities, for the condition of (SARS-CoV-2) COVID-19 according to the following characteristics: a) Positive, b) Negative, c) Suspicious. Likewise, it presents information related to the identification of an outpatient and / or hospitalized patient, attending to their medical development, identifying: a) Recovered, b) Deaths and c) Active, in Phase 3 and Phase 4, in the five main population areas speaker of indigenous language in the State of Veracruz - Mexico. The data analysis is carried out through the application of a data mining algorithm, which provides the information, fast and timely, required for the estimation of Medical Care Scenarios of (SARS-CoV-2) COVID-19, as well as for know the impact on the indigenous language speaking population in Veracruz. For this purpose, the following study zones are presented: a) Totonacapan Zone, b) Huasteco from the Tantoyuca Zone, c) Otomi from the Inxhuatlan de Madero Zone, d) Nahuatl from the Zongolica Zone, e) Nahuatl from the Chicontepec Zone, f) Nahualt from the Pajapan Zone and g) Popoluca from the Soteapan Zone. This data article presents the information as of August 1, 2020 corresponding to the Totonacapan Area.
\end{abstract}

\section{Keywords}

(SARS-CoV-2) COVID-19, Algorithm (SARS-CoV-2) COVID-19, Mexico, identification of patients, Totonacapan Area.

Specifications Table

\begin{tabular}{|l|l|}
\hline Subject & Infectious Diseases \\
\hline Specific subject area & $\begin{array}{l}\text { Information from the Viral Respiratory Diseases Epidemiological } \\
\text { Surveillance System for (SARS-CoV-2) COVID-19 in Mexico corresponding } \\
\text { to the Totonacapan Area }\end{array}$ \\
\hline
\end{tabular}




\begin{tabular}{|c|c|}
\hline Type of data & $\begin{array}{l}\text { Table } \\
\text { Figure }\end{array}$ \\
\hline How data were acquired & $\begin{array}{l}\text { Government of Mexico. Health Secretary. Databases Covid-19 México } \\
\text { https://datos.gob.mx/busca/dataset/informacion-referente-a-casos- } \\
\text { covid-19-en-mexico/resource/e8c7079c-dc2a-4b6e-8035-08042ed37165 } \\
\text { Instruments: } \\
\text { Software Orange Data Mining version 3.26.0 https://orange.biolab.si } \\
\text { Make and model and of the instruments used: } \\
\text { Algorithm for the identification of patients according to following } \\
\text { characteristics: a) Positive, b) Negatives, c) Suspects. Likewise, it presents } \\
\text { information regarding the identification of an outpatient and / or } \\
\text { hospitalized patient, attending to their medical development, identifying: } \\
\text { a) Recovered, b) Deaths and c) Assets }\end{array}$ \\
\hline Data format & $\begin{array}{l}\text { The information is presented in raw in CVS format, the Ministry of Health } \\
\text { of Mexico since April 14, } 2020 \text { published the cases associated with (SARS- } \\
\text { CoV-2) COVID-19 as open data. The data processing corresponds to the } \\
\text { records on the epidemic (SARS-CoV-2) COVID-19 at } 1 \text { August 2020. The } \\
\text { treatment of the information is carried out through the application } \\
\text { software for data mining Orange version 3.26.0, in which the algorithm for } \\
\text { the analysis of information is filtered to present the current scenario in } \\
\text { Totonacapan Area in Mexico of the SARS-CoV-2 (COVID 19). }\end{array}$ \\
\hline $\begin{array}{l}\text { Parameters for data } \\
\text { collection }\end{array}$ & $\begin{array}{l}\text { The information is presented at the municipal, state and national levels, } \\
\text { with a daily registry of patients, according to age, sex, comorbidities, for } \\
\text { the condition of (SARS-CoV-2) COVID-19 according to the following } \\
\text { characteristics: a) Positive, b) Negatives, c) Suspects. Likewise, it presents } \\
\text { information regarding the identification of an outpatient and / or } \\
\text { hospitalized patient, attending to their medical development, identifying: } \\
\text { a) Recovered, b) Deaths and c) Assets. }\end{array}$ \\
\hline Study area & $\begin{array}{l}\text { The municipalities that comprise Totonaco from the Totonacapan area of } \\
\text { the Costa are: Cazones, Chumatlan, Coahuitlan, Coatzintla, Coxquihui, } \\
\text { Coyutla, Espinal, Filomeno Mata, Gutierrez Zamora, Mecatlan, Papantla, } \\
\text { Poza Rica de Hidalgo, Tecolutla, Tihuatlán and Zozocolco de Hidalgo. }\end{array}$ \\
\hline $\begin{array}{l}\text { Description of data } \\
\text { collection }\end{array}$ & $\begin{array}{l}\text { This information is filtered to present the current scenario in Mexico of } \\
\text { the SARS-CoV-2 (COVID 19) in a fast and timely manner, to support public } \\
\text { decision-making in health matters. }\end{array}$ \\
\hline Data source location & $\begin{array}{l}\text { Institution: Universidad Veracruzana / Instituto de Investigaciones y } \\
\text { Estudios Superiores Económicos y Sociales } \\
\text { Country: México }\end{array}$ \\
\hline Data accessibility & $\begin{array}{l}\text { Raw data can be retrieved from the Github repository } \\
\text { https://github.com/CMedelR/dataCovid19/edit/master/README.md }\end{array}$ \\
\hline
\end{tabular}

\section{Value of the Data}


- The Algorithm for the identification of patients (SARS-CoV-2) COVID 19 in Mexico allows to analyze at the municipal, state and national level, the registry of patients, according to age, sex, comorbidities, for condition of (SARS-CoV-2) COVID-19 according to the following characteristics: a) Positive, b) Negative, c) Suspicious, as well as presenting information on the identification of an outpatient and / or hospitalized patient, attending to their medical development, identifying: a) Recovered, b ) Deaths and c) Assets, in Phase 3 and Phase 4, in a fast and timely manner, to support public decision-making in health matters.

- Taking into account their strategic roles in public health and researchers can use the data from this study to identify the action scenario for decision-making in the combat of (SARS-CoV-2) COVID 19 in Phase 3 and Phase 4 corresponding to the Totonacapan Area.

- The importance of data analysis is that it allows identifying cases (SARS-CoV-2). COVID-19 in Mexico is concentrated daily and knowing the impact on the population and allows preparing action scenarios to make public health policy decisions to combat SARS-CoV-2) COVID-19 in the main five areas that concentrate the speaking population of Nahuatl, Totonaco, Huasteco, Popoluca, Otomi in Veracruz Mexico.

\section{Data Description}

The source of information on the number of registered cases of (SARS-CoV-2) COVID-19 at 1 August 2020 for Mexico comes from the website https://datos.gob.mx/busca/dataset/informacion-referente-a-casoscovid-19-en-mexico by the Ministry of Health, with the participation of the National Council for Science and Technology (CONACYT), the Center for Research in Geospatial Information Sciences (CENTROGEO), the National Laboratory for Geo-Intelligence (GEOINT), the Data Laboratory of the National Laboratory for Geointelligence (DataLab), where the registry of COVID-19 cases (SARS-CoV-2) COVID-19 is concentrated, and is the official means of communication and information on the epidemic in the Totonacapan Area in Mexico.

The information of the cases (SARS-CoV-2) COVID-19 in Mexico is concentrated on a daily basis since April 19, 2020, communication and official information on the epidemic in Mexico, the data are presented at the municipal, state and national levels, with a daily registry of patients, according to age, sex, comorbidities, for the condition of (SARS-CoV-2) COVID-19 according to the following characteristics: a) Positive, b) Negatives, c) Suspects. Likewise, it presents information regarding the identification of an outpatient and / or hospitalized patient, attending to their medical development, identifying: a) Recovered, b) Deaths and c) Assets. The data processing corresponds to the records on the epidemic (SARS-CoV-2) COVID-19 at 1 August 2020. The treatment of the information is carried out through the application software for data mining and visual programming Orange Data Mining version 3.26.0. Orange Data Mining is a machine learning and data mining suite for data analysis through Python scripting and visual programming. [1]

According to (WHO, 2020) the (SARS-CoV-2) COVID-19 disease pattern presents 4 scenarios identified from the confirmation of Laboratory Diagnosis: a) Not Infected or b) Infected, in this finally, the following categories are observed, taking into account age and specific comorbidities in each case: a) Mild Infection, b) Moderate Infection, c) Severe Infection and d) Critical Infection.

Depending on the category observed in Patients who have a Confirmation of Infected, as in the case of a) or b) it can assume the character of Outpatient, so the strategy is isolation or "quarantine" at home, where the result It is hoped that he will recover. Regarding the Patients who have a Confirmation of Infected, in categories c) and d) they assume the character of Hospitalized Patient, with a probability of requiring care in Intensive Care Units and requiring Intubation, and where it is hoped to save as many patients as possible. 
The importance of the research is that it allows identifying the action scenario for making public health policy decisions to combat CO(SARS-CoV-2) COVID-19, since they consider the following states of process in medical treatment, in order to carry out the Estimate of Scenarios for Medical Care of the (SARS-CoV-2) COVID-19 under the following premises of hospital care:

1. A patient with a positive (SARS-CoV-2) COVID-19 laboratory diagnosis can be considered: a) Outpatient, or b) Hospitalized.

2. If the (SARS-CoV-2) COVID-19 Positive patient is Hospitalized, the following should be considered: a) Enter the Intensive Care Unit or b) Do not enter the Intensive Care Unit.

3. If the (SARS-CoV-2) COVID-19 Positive patient is Hospitalized and Entered into the Intensive Care Unit, the following should be considered: a) The patient requires intubation or $b$ ) The patient does NOT require intubation.

\section{Methods}

The information is presented in raw in CVS format, the Ministry of Health of Mexico. The data processing corresponds to the records on the epidemic (SARS-CoV-2) COVID-19 at 1 August 2020. The treatment of the information is carried out through the application software for data mining Orange version 3.26.0, in which the algorithm for the analysis of information are developed and it is filtered to present the current scenario in Mexico of the SARS-CoV-2 (COVID 19). In this way, the algorithm that is presented allows us to project the requirements for the use of installed infrastructure in the face of the growing requirement for patient care Positive (SARS-CoV-2) COVID-19, allowing the identification of scenarios at the national, state and municipal levels. The construction of the algorithm is based on the following definitions.

Definition 1: Total Patients to consider in Model (SARS-CoV-2) COVID-19.- It is the number of total patients according to the confirmatory laboratory result or not of (SARS-CoV-2) COVID-19).

Be:

TP SARS-CoV-2 $\mathrm{i}$ j = Total patients according to (SARS-CoV-2) COVID-19 confirmatory laboratory result Which consists of:

TP SARS-CoV-2 $\mathrm{i} j=(P+$ SARS-CoV-2 $\mathrm{i} j)+(P-$ SARS-CoV-2 $\mathrm{i} j)+($ Px SARS-CoV-2 $\mathrm{i} j)$, where: $i=$ State, $j=$ Municipality

Of which:

P+ SARS-CoV-2 $\mathrm{i} j$ = Patient with a positive (SARS-CoV-2) COVID-19 result in the State, Municipality

P- SARS-CoV-2 $\mathrm{i} j$ = Patient with negative (SARS-CoV-2) COVID-19 result in the State, Municipality

Px SARS-CoV-2 $\mathrm{i}$ j = Patient with pending confirmation (SARS-CoV-2) COVID-19 in the State, Municipality

Definition 2: Identification of a suspected (SARS-CoV-2) COVID-19 case.- This is the patient who undergoes an initial qualification according to the initial diagnostic characteristics indicated in the case definitions for surveillance by the World Health Organization for primary care of (SARS-CoV-2) COVID-19 cases.

Be:

CSCOVID 19 (SARS-CoV-2) = Patient with initial classification as a suspected case of (SARS-CoV-2) COVID-19 Where:

Cs (SARS-CoV-2) COVID-19 = Cs (SARS-CoV-2) COVID-19 Type $1+$ Cs (SARS-CoV-2) COVID-19 Type 2 + Cs (SARSCoV-2) COVID-19 Type 3

Of which:

According to the World Health Organization, there are 3 categories (identified as Type 1, Type 2 and Type 3) to identify suspected cases of (SARS-CoV-2) COVID-19, defined below:

1. Cs (SARS-CoV-2) COVID-19 Type 1.- Is a patient with acute respiratory disease (fever and at least one sign / symptom of respiratory disease, with no other aetiology that fully explains the clinical presentation and a history of travel or residence in a country / area or territory that reports local transmission of COVID-19 disease during the 14 days prior to the onset of symptoms. 
2. Cs (SARS-CoV-2) COVID-19 Type 2.- He is a patient with an acute respiratory disease, who has been in contact with a confirmed or probable COVID-19 case in the last 14 days before the onset of symptoms.

3. Cs (SARS-CoV-2) COVID-19 Type 3.- Is a patient with severe acute respiratory infection (fever and at least one sign / symptom of respiratory illness (eg cough, shortness of breath) and requiring hospitalization and without another etiology that fully explains the clinical presentation.

Definition 3: Total Patients to consider in the (SARS-CoV-2) COVID-19 Model .- It is the number of total patients according to the confirmatory laboratory result or not of (SARS-CoV-2) COVID-19).

Be:

TP SARS-CoV-2 $\mathrm{i}$ j = Total patients according to confirmatory laboratory result or not of (SARS-CoV-2) COVID19

Which consists of:

TP SARS-CoV-2 $\mathrm{i} j=(P+$ SARS-CoV-2 $\mathrm{i} j)+(P-$ ARS-CoV- $2 \mathrm{i} j)+(P x$ ARS-CoV- $2 \mathrm{i} j)$, where: $\mathrm{i}=$ State, $\mathrm{j}=$ Municipality

Of which:

$\mathrm{P}+$ SARS-CoV-2 $\mathrm{i}$ = Patient with a positive (SARS-CoV-2) COVID-19 result in the State, Municipality

P- ARS-CoV-2 $\mathrm{i}$ = Patient with negative (SARS-CoV-2) COVID-19 result in the State, Municipality

Px ARS-CoV-2 i j = Patient with pending confirmation (SARS-CoV-2) COVID-19 in the State, Municipality

Definition 4: Positive Patients for (SARS-CoV-2) COVID-19 i j.- It is the number of patients with laboratory results with positive confirmation for (SARS-CoV-2) COVID-19 $\mathrm{i}$.

It has:

$\mathrm{P}+\mathrm{SARS}-\mathrm{CoV}-2 \mathrm{i} \mathrm{j}=$ Patient with a positive (SARS-CoV-2) COVID-19 result in the State, Municipality

Definition 5.- Medical Treatment Strategy for a patient with positive laboratory confirmation for (SARS-CoV2) COVID-19 i $\mathrm{j}$.- It is the Action Plan in Medical Treatment for a patient with positive laboratory confirmation for SARS-CoV-2 in attention to your degree of infection and comorbidities present that is channeled to determine the Physician.

According to the Strategy of Medical Care required for Patients with a Positive SARS-CoV-2 Result, according to their degree of identified infection, they have the following.

Be:

ET P + SARS-CoV-2 i j = Medical Treatment Strategy P + SARS-CoV-2 i j

The medical treatment for a patient with a positive laboratory result for (SARS-CoV-2) COVID-19, based on the Medical Treatment Strategy (ETM P + SARS-CoV-2 ij), based on his degree of infection and present comorbidities, poses two action scenarios : i) Outpatient (SARS-CoV-2) COVID-19 patient or ii) Hospitalized (SARS-CoV-2) COVID-19 patient.

Be:

i) Outpatient COVID19 patient.

$\mathrm{P}+$ SARS-CoV-2 i j Outpatient $=$ Positive (SARS-CoV-2) COVID-19 with Outpatient mode in the State, Municipality

ii) COVID19 Patient Hospitalized.

P + SARS-CoV-2 i j Hospitalized = Positive (SARS-CoV-2) COVID-19 with modality Hospitalized in the State, Municipality

where:

Depending on the degree of infection (I1, 12 or 13), the Hospitalized (SARS-CoV-2) COVID-19 Patient may require: i) Access to the Intensive Care Area without Intubation or ii) Access to the Intensive Care Area with Intubation. 
Definition 6.- Patients with a Positive (SARS-CoV-2) COVID-19 Result Hospitalized with Access to the Intensive Care area.- It is the number of Patients with a Positive SARS-CoV-2 Result Hospitalized with Access to the Intensive Care area, according to its degree of infection.

Be:

P + SARS-CoV-2 i j Hospital Intensive Care = Positive (SARS-CoV-2) COVID-19 with modality

Hospitalized in the State, Municipality

Definition 7.- Patients with a positive (SARS-CoV-2) COVID-19 result Hospitalized with access to the Intensive Care Area with Intubation.- It is the number of Patients with a Positive (SARS-CoV-2) COVID-19 Result Hospitalized with Access to the Intensive Care area with Intubation.

Be:

P + SARS-CoV-2 i j Hospital Intensive Care with Intubation = Positive (SARS-CoV-2) COVID-19 with Hospitalized modality and intubation in the State, Municipality.

Definition 8.- $P+$ SARS-CoV-2 i j Deaths.- Deaths of Patients with a positive result for SARS-CoV-2. Deaths are all those positive to (SARS-CoV-2) COVID-19 where one is indicated in the data record (DATE_DEF other than the value "99-99-9999").

Definition 9.- (SARS-CoV-2) COVID-19 case fatality rate.- It is the proportion of people who die from (SARSCoV-2) COVID-19 among the Patients with a positive (SARS-CoV-2) COVID-19 result in a given period and area. Be:

TL SARS-CoV-2 i j = (SARS-CoV-2) COVID-19 case fatality rate Where:

(SARS-CoV-2) COVID-19 case fatality rate $=$ [(Deaths of Patients with a Positive (SARS-CoV-2) COVID-19 Result in the State or Municipality) / (Total of Patients with a Positive (SARS-CoV-2) COVID-19 result in the State or Municipality)] x 100

Of which:

DP+ SARS-CoV-2 $\mathrm{i} j$ = Deaths of Patients with a positive (SARS-CoV-2) COVID-19 result in the State / Municipality

And:

P+ SARS-CoV-2 i j = Total Patients with a positive (SARS-CoV-2) COVID-19 result in the State / Municipality So:

TL SARS-CoV-2 i j = [D P + SARS-CoV-2 i j $P$ + SARS-CoV-2 i j] $\times 100$

The data processing corresponds to the records on the epidemic (SARS-CoV-2) COVID-19 at 1 August 2020. The treatment of the information is carried out through the application software for data mining Orange version 3.26.0, in which the algorithm for the information analysis are developed. (See Figure 1, below). According to information from the Ministry of Health, the following records are available at the national level: 
Figure 1. Algorithm for the identification of patients (SARS-CoV-2) COVID 19 in the Totonacapan Zone in Mexico

Orange Data Mining version 3.26.0

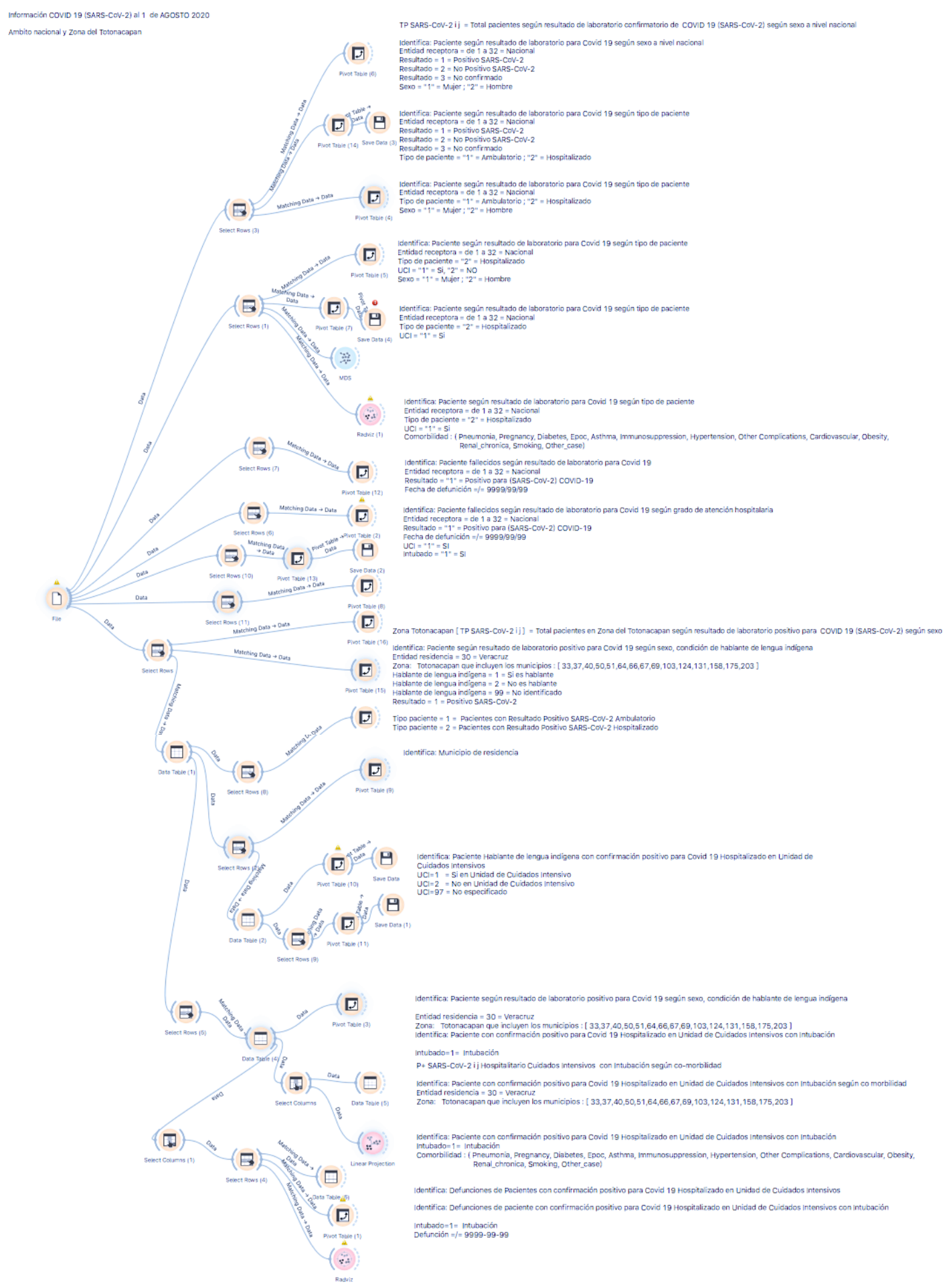


According to information from the Ministry of Health in Mexico, the following records are available at the national level:

1. The total number of cases in Mexico as of august 1, 2020, is 999,697 cases of which, based on the confirmatory or non-laboratory result for (SARS-CoV-2) COVID-19, the following classification is obtained: a ) 434,193 patients with a positive result for (SARS-CoV-2) COVID-19, b) 477,733 patients with a non-positive result for (SARS-CoV-2) COVID-19 and c) 87,771 patients with a pending result to determine (SARS-CoV -2) COVID-19. (See table 1)

2. The number of patients with a positive (SARS-CoV-2) COVID-19 result is 434,193 of which: a) 316,860 are care outpatients and b) 117,333 are hospitalized patients. (See table 2)

3. The total number of patients (SARS-CoV-2) COVID-19 hospitalized (include positive and non positive results) is 192,214 of whom 78,088 are women and 114,126 are men. (See Table 3)

4. The total number of hospitalized patients with a positive result for (SARS-CoV-2) COVID-19 is 117,219, of whom: a) 9,400 patients enter the intensive care unit; while b) 107,819 patients do not enter the intensive care unit. (See Table 4)

5. Only 4,874 Hospitalized with a positive (SARS-CoV-2) COVID-19 patients admitted to the intensive care unit required intubation; while 4,526 patients did not require intubation. (See Table 5 )

6. Likewise, to date 42,158 deaths from positive (SARS-CoV-2) COVID-19 patients have been registered nationwide, of which 3,486 deaths corresponded to Positive (SARS-CoV-2) COVID-19 patients who were in intensive care and intubation and 38,672 corresponded to (SARS-CoV-2) COVID-19 positive patients who were not in intensive care. (See Table 6).

7. The fatality rate of patients with a positive result for SARS-CoV-2) COVID-19 at nationwide as of august 1,2020 , is estimated at $10.93 \%$. The five states that registered the highest fatality rates as of August 1, 2020 are the following: a) Morelos with a rate of 2039\%, b) Baja California with 19.67\%, c) Sinaloa with a rate of $17.46 \%$, d) Colima with a rate of 17: $00 \%$ and e) State of Mexico with a rate of $15.37 \%$. For its part, the State of Veracruz registered a rate of $13.20 \%$ while Mexico City registered a rate of $9.75 \%$ (See Table 7 ).

8. Figure 1 shows the main comorbidities identified in hospitalized patients with a positive result for (SARS-CoV-2) COVID-19, nationwide as of August 1, 2020.

9. In the State of Veracruz, the total number of cases related to (SARS-CoV-2) COVID-19 as of August 1, 2020 is 34,904 of which: a) 21,582 correspond to patients with positive confirmation for (SARS-CoV2) COVID-19, b) 10,518 are patients with a negative result for (SARS-CoV-2) COVID-19 and c) 2,804 are patients with results pending confirmation. (See Table 8 ).

10. In the State of Veracruz, $4.97 \%$ of all patients with a positive result for (SARS-CoV-2) COVID-19 are concentrated at the national level as of August 1, 2020. (See Table 1 and Table 8).

11. For its part, in the Totonacapan Zone the total number of cases related to (SARS-CoV-2) COVID-19 as of August 1, 2020 is 1,868 of which: a) 1,225 correspond to patients with positive confirmation for (SARS- CoV- 2) COVID-19, b) 498 are patients with a negative result for (SARS-CoV-2) COVID-19 and c) 145 are patients with results pending confirmation. (See Table 9).

12. The percentage of Totonaco-speaking patients with a positive result for (SARS-CoV-2) COVID-19 is $2.28 \%$ with respect to the total number of cases registered in the Totonacapan Area. (See Table 9 and Table 10). 
According to information from the Ministry of Health, in the Totonacapan Zone the following records are available at the national level:

1. The number of patients with a positive (SARS-CoV-2) COVID-19 result is 1,617 of which: a) 689 are women and b) 928 are men. The total number of women with a positive (SARS-CoV-2) COVID-19, only 6 are women who speak the indigenous language and 699 are women who do not speak the indigenous language. On the other hand, the total number of men with a positive (SARS-CoV-2) COVID-19, 22 are men who speak the indigenous language and 906 are men who do not speak the indigenous language. (See Table 10).

2. From the 1,617 patients with (SARS-CoV-2) positive COVID-19, according to their primary hospital care, there are: a) 971 are patients who did not require hospitalization and b) 646 are patients who required hospitalization. From the 646 patients with (SARS-CoV-2) COVID-19 positive who were hospitalized: a) 18 correspond to speakers of the indigenous language and b) 628 are patients who do not speak the indigenous language. The 971 patients with (SARS-CoV-2) COVID19 positive who were not hospitalized, only 10 were patients speaking the indigenous language and 961 were patients who did not speak the indigenous language. (See Table 11).

3. From the 28 patients who speak the indigenous language, these come from: Coatzintla 1 patient, Coxquihui 2, Coyutla 2, Chumatlán 1, Espinal 1, Papantla 12, Poza Rica 8 and Zozocolco de Hidalgo 1. (See Table 12)

4. From the 646 hospitalized (SARS-CoV-2) COVID-19 positive patients: a) 5 patients enter the Intensive Care Unit; while b) 186 patients do not enter the Intensive Care Unit. Only 5 Hospitalized (SARS-CoV-2) COVID-19 Positive patients admitted to the Intensive Care Unit required intubation, 1 in Coatzintla, 1 in Espinal and 3 in Papantla (See Table 13).

5. As of August 1, 2020 there have been 3 deaths of hospitalized patients (SARS-CoV-2) COVID-19 whose results were positive and were indigenous language speakers in the Totonacapan zone. (See Figure 2, at the end of the section, where the associated comorbidities of the indigenous language-speaking patients who died in the Totonacapan Zone, as August 12020. 
Table 1. Total number of cases in Mexico 1 August 2020, According to Sex and Result at (SARS-CoV-2) COVID-19

\begin{tabular}{lrrr}
\hline & \multicolumn{2}{c}{ Sex } & \\
\cline { 2 - 3 } \multicolumn{1}{c}{ Result } & \multicolumn{1}{c}{ Women } & \multicolumn{1}{c}{ Men } & Total \\
\hline Positive (SARS-CoV-2) COVID-19 & 203,284 & 230,909 & 434,193 \\
No positive (SARS-CoV-2) COVID-19 & 254,331 & 223,402 & 477,733 \\
Pending result & 43,466 & 44,305 & 87,771 \\
Total & 501,081 & 498,616 & 999,697 \\
\hline
\end{tabular}

Source: Government of Mexico. Health Secretary. Information from the Epidemiological Surveillance System for Viral Respiratory Diseases 1 August 2020

Table 2. Total number of cases in Mexico as of August 1, 2020, according to type of patient and result in (SARS-CoV-2) COVID-19

\begin{tabular}{lrrr}
\hline & \multicolumn{2}{c}{ Patient type } & \\
\cline { 2 - 3 } \multicolumn{1}{c}{ Result } & 316,860 & 117,333 & 434,193 \\
\cline { 2 - 3 } Positive (SARS-CoV-2) COVID-19 & Ambulatory & Hospitalized & Total \\
No positive (SARS-CoV-2) COVID-19 & 418,514 & 59,219 & 477,733 \\
Pending result & 72,109 & 15,662 & 87,771 \\
Total & 807,483 & 192,214 & 999,697 \\
\hline
\end{tabular}

Source: Government of Mexico. Health Secretary. Information from the Epidemiological Surveillance System for Viral Respiratory Diseases 1 August 2020

Table 3. Total number of cases in Mexico as of August 1, 2020, according to sex and type of patient

\begin{tabular}{lrrr}
\hline & \multicolumn{2}{c}{ Patient type } & \\
\cline { 2 - 3 } \multicolumn{1}{r}{ Sex } & Ambulatory & Hospitalized & Total \\
\hline Women & 422,993 & 78,088 & 501,081 \\
Men & 384,490 & 114,126 & 498,616 \\
Total & 807,483 & 192,214 & 999,697 \\
\hline
\end{tabular}

Source: Government of Mexico. Health Secretary. Information from the Epidemiological Surveillance System for Viral Respiratory Diseases 1 August 2020 
Table 4. Total number of cases in Mexico as of August 1, 2020, according type of patient and Intensive care unit

\begin{tabular}{lccc}
\hline Patient type & $\begin{array}{c}\text { Intensive care } \\
\text { unit }\end{array}$ & $\begin{array}{c}\text { No Intensive care } \\
\text { unit }\end{array}$ & Total \\
\hline Hospitalized & 9,400 & 107,819 & 117,219 \\
\hline
\end{tabular}

Source: Government of Mexico. Health Secretary. Information from the Epidemiological Surveillance System for Viral Respiratory Diseases 1 August 2020

Table 5. Total number of cases in Mexico as of August 1, 2020, according to hospitalized patient in intensive care unit and intubation condition

\begin{tabular}{lccc}
\hline \multicolumn{1}{c}{ Patient type } & $\begin{array}{c}\text { Intubated } \\
\text { patient }\end{array}$ & $\begin{array}{l}\text { No Intubated } \\
\text { patient }\end{array}$ & Total \\
\hline $\begin{array}{l}\text { Hospitalized } \\
\text { intensive care }\end{array}$ & 4,874 & 4,526 & 9,400 \\
unit & & & \\
\hline
\end{tabular}

Source: Government of Mexico. Health Secretary. Information from the Epidemiological Surveillance System for Viral Respiratory Diseases 1 August 2020

Table 6. Number of deceased patients with positive COVID-19 (SARSCoV-2), nationwide and according to hospital care condition as of August 1, 2020

\begin{tabular}{lccc}
\hline \multicolumn{1}{c}{ Patient type } & Women & Men & Total \\
\hline $\begin{array}{l}\text { At the national } \\
\text { level }\end{array}$ & 14,878 & 27,280 & 42,158 \\
$\begin{array}{l}\text { Intensive care } \\
\text { unit patients with } \\
\text { intubation }\end{array}$ & 1,085 & 2,401 & 3,486 \\
$\begin{array}{l}\text { \% Deceased } \\
\text { patients requiring } \\
\text { care in intensive } \\
\text { care units and } \\
\text { intubation, by sex }\end{array}$ & $7.3 \%$ & & \\
\hline
\end{tabular}

Source: Government of Mexico. Health Secretary. Information from the Epidemiological Surveillance System for Viral Respiratory Diseases 1 August 2020 
Table 7. (SARS-CoV-2) COVID-19 fatality rate by state in Mexico as of August 1, 2020

\begin{tabular}{|c|c|c|c|c|}
\hline & Estado & Total deceased & Covid positives 19 & Case fatality rate \\
\hline 1 & Aguascalientes & 257 & 4,120 & $6.24 \%$ \\
\hline 2 & Baja California & 2,674 & 13,594 & $19.67 \%$ \\
\hline 3 & Baja California Sur & 182 & 4,498 & $4.05 \%$ \\
\hline 4 & Campeche & 500 & 4,588 & $10.90 \%$ \\
\hline 5 & Chiapas & 645 & 13,116 & $4.92 \%$ \\
\hline 6 & Chihuahua & 194 & 1,875 & $10.35 \%$ \\
\hline 7 & Ciudad de México & 7,244 & 74,314 & $9.75 \%$ \\
\hline 8 & Coahuila de Zaragoza & 967 & 5,775 & $16.74 \%$ \\
\hline 9 & Colima & 904 & 5,317 & $17.00 \%$ \\
\hline 10 & Durango & 288 & 4,167 & $6.91 \%$ \\
\hline 11 & Guanajuato & 1,009 & 21,378 & $4.72 \%$ \\
\hline 12 & Guerrero & 1,415 & 11,032 & $12.83 \%$ \\
\hline 13 & Hidalgo & 1,033 & 6,901 & $14.97 \%$ \\
\hline 14 & Jalisco & 1,549 & 13,313 & $11.64 \%$ \\
\hline 15 & México & 8,225 & 53,513 & $15.37 \%$ \\
\hline 16 & Michoacán de Ocampo & 780 & 9,910 & $7.87 \%$ \\
\hline 17 & Morelos & 836 & 4,101 & $20.39 \%$ \\
\hline 18 & Nayarit & 391 & 3,518 & $11.11 \%$ \\
\hline 19 & Nuevo León & 1,118 & 18,032 & $6.20 \%$ \\
\hline 20 & Oaxaca & 968 & 10,673 & $9.07 \%$ \\
\hline 21 & Puebla & 2,446 & 20,355 & $12.02 \%$ \\
\hline 22 & Querétaro & 449 & 3,726 & $12.05 \%$ \\
\hline 23 & Quintana Roo & 1,015 & 7,840 & $12.95 \%$ \\
\hline 24 & San Luis Potosí & 522 & 9,921 & $5.26 \%$ \\
\hline 25 & Sinaloa & 2,230 & 12,774 & $17.46 \%$ \\
\hline 26 & Sonora & 1,949 & 17,890 & $10.89 \%$ \\
\hline 27 & Tabasco & 1,988 & 21,747 & $9.14 \%$ \\
\hline 28 & Tamaulipas & 1,008 & 17,130 & $5.88 \%$ \\
\hline 29 & Tlaxcala & 713 & 4,627 & $15.41 \%$ \\
\hline 30 & Veracruz de Ignacio de la Llave & 2,849 & 21,582 & $13.20 \%$ \\
\hline 31 & Yucatán & 875 & 10,098 & $8.67 \%$ \\
\hline \multirow[t]{2}{*}{32} & Zacatecas & 249 & 2,768 & $9.00 \%$ \\
\hline & Total & 47,472 & 434,193 & $10.93 \%$ \\
\hline
\end{tabular}

Source: Own elaboration with Government of Information from the Mexico. Health Secretary. Epidemiological Surveillance System for Viral Respiratory Diseases as of August 1, 2020 
Figure 1 Comorbidities identified in hospitalized patients with a positive result for (SARS-CoV-2) COVID-19, nationwide as of August 1, 2020

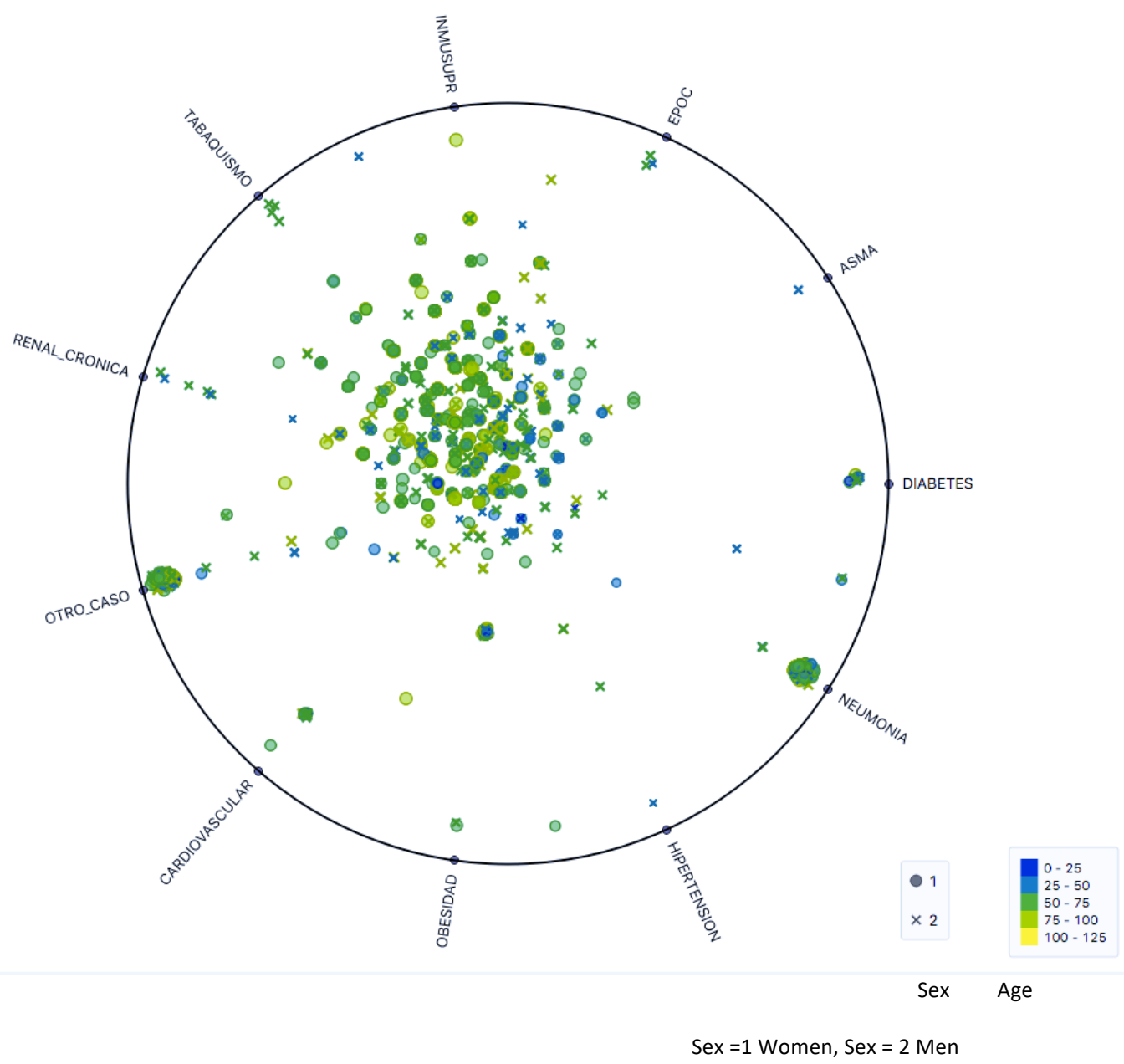

Source: Own elaboration with Government of Information from the Mexico. Health Secretary. Epidemiological Surveillance System for Viral Respiratory Diseases as of August 1, 2020 
Table 8. Total number of cases in Veracruz State as of August 1, 2020, According to Sex and Result at (SARS-CoV-2) COVID-19

\begin{tabular}{lrrr}
\hline \multicolumn{1}{c}{ Result } & \multicolumn{2}{c}{ Sex } & Total \\
\cline { 1 - 3 } Positive (SARS-CoV-2) COVID-19 & 9,250 & \multicolumn{1}{c}{ Men } & 12,332 \\
No positive (SARS-CoV-2) COVID-19 & 5,663 & 4,865 & 10,518 \\
Pending result & 1,285 & 1,519 & 2,804 \\
Total & 16,198 & 18,706 & 34,904 \\
\hline
\end{tabular}

Source: Own elaboration with Government of Information from the Mexico. Health Secretary. Epidemiological Surveillance System for Viral Respiratory Diseases as of August 1, 2020

Table 9. Total number of cases in Totonacapan Zone in Mexico as of August 1, 2020, According to Sex and Result at (SARS-CoV-2) COVID-1

\begin{tabular}{lrrr}
\hline \multicolumn{1}{c}{ Result } & Women & Men & Total \\
\hline Positive (SARS-CoV-2) COVID-19 & 518 & 707 & 1,225 \\
No positive (SARS-CoV-2) COVID-19 & 251 & 247 & 498 \\
Pending result & 70 & 75 & 145 \\
Total & 839 & 1,029 & 1,868 \\
\hline
\end{tabular}

Source: Own elaboration with Government of Information from the Mexico. Health Secretary. Epidemiological Surveillance System for Viral Respiratory Diseases as of August 1, 2020

Table 10. Total number of cases with result positive at (SARS-CoV-2) COVID-19 in the Totonacapan Zone Mexico as of August 1, 2020, according to sex, indigenous language speaker status and

\begin{tabular}{lrrr}
\hline \multicolumn{1}{c}{ Result } & Women & Men & Total \\
\hline Indigenous language speaker & 6 & 22 & 28 \\
Non-indigenous language speaker & 677 & 898 & 1,575 \\
Not specified & 6 & 8 & 14 \\
Total & 689 & 928 & 1,617 \\
\hline
\end{tabular}

Source: Own elaboration with Government of Information from the Mexico. Health Secretary. Epidemiological Surveillance System for Viral Respiratory Diseases as of August 1, 2020, 
Table 11. Total number of cases with result positive at (SARS-CoV-2) COVID-19 in the Totonacapan Zone in Mexico as of August 1, 2020, according to primary hospital care condition and indigenous language speaker status

\begin{tabular}{lcccr}
\hline \multicolumn{1}{c}{ Result } & Non & Hospitalized & Hospitalized & Total \\
\hline Indigenous language speaker & 10 & 18 & 28 \\
Non-indigenous language speaker & 956 & 619 & 1,575 \\
Not specified & 5 & 9 & 14 \\
Total & 971 & 646 & 1,617 \\
\hline
\end{tabular}

Source: Own elaboration with Government of Information from the Mexico. Health Secretary. Epidemiological Surveillance System for Viral Respiratory Diseases as of August 1, 2020

Table 12. Total number of cases with result positive at (SARS-CoV-2) COVID-19 in the Totonacapan Zone in Mexico as of August 1, 2020, according to primary indigenous language speaker status and municipality

\begin{tabular}{|c|c|c|c|c|}
\hline Municipality & $\begin{array}{c}\text { Speak } \\
\text { indigenous } \\
\text { language }\end{array}$ & $\begin{array}{c}\text { Non } \\
\text { Speak } \\
\text { indigenous } \\
\text { language } \\
\end{array}$ & Not specified & Total \\
\hline \multicolumn{5}{|l|}{ Cazones de } \\
\hline Herrera & 0 & 17 & 0 & 17 \\
\hline Coatzintla & 1 & 135 & 1 & 137 \\
\hline Coxquihui & 2 & 5 & 0 & 7 \\
\hline Coyutla & 2 & 6 & 0 & 8 \\
\hline Chumatlán & 1 & 0 & 0 & 1 \\
\hline Espinal & 1 & 10 & 0 & 11 \\
\hline Filomeno Mata & 0 & 1 & 0 & 1 \\
\hline Gutierrez Zamora & 0 & 28 & 0 & 28 \\
\hline Mecatlan & 0 & 2 & 0 & 2 \\
\hline Papantla & 12 & 232 & 2 & 246 \\
\hline Poza Rica & 8 & 1,015 & 10 & 1,033 \\
\hline Tecolutla & 0 & 15 & 0 & 15 \\
\hline Tihuatlán & 0 & 108 & 1 & 109 \\
\hline \multicolumn{5}{|l|}{ Zozocolco de } \\
\hline Hidalgo & 1 & 1 & 0 & 2 \\
\hline Total & 28 & 1,575 & 14 & 1,617 \\
\hline
\end{tabular}

Source: Own elaboration with Government of Information from the Mexico. Health Secretary. Epidemiological Surveillance System for Viral Respiratory Diseases as of August 1, 2020 
Table 13. Total number of cases with result positive at (SARS-CoV-2) COVID-19 in the Totonacapan Zone in Mexico as of August 1, 2020, according to primary indigenous language speaker status and status according to primary hospital care condition in Intensive care unit

\begin{tabular}{lrrrr}
\hline \multicolumn{1}{c}{ Municipality } & $\begin{array}{c}\text { Intensive } \\
\text { care unit }\end{array}$ & $\begin{array}{c}\text { Non Intensive } \\
\text { care unit }\end{array}$ & $\begin{array}{c}\text { Not } \\
\text { specified }\end{array}$ & Total \\
\hline Cazones de Herrera & 0 & 4 & 0 & 4 \\
Coatzintla & 1 & 10 & 1 & 12 \\
Coxquihui & 0 & 1 & 0 & 1 \\
Coyutla & 0 & 3 & 0 & 3 \\
Espinal & 1 & 1 & 0 & 2 \\
Gutierrez Zamora & 0 & 5 & 0 & 5 \\
Papantla & 3 & 19 & 0 & 22 \\
Poza Rica & 0 & 115 & 2 & 117 \\
Tihuatlán & 0 & 24 & 0 & 24 \\
Total & 5 & 183 & 3 & 191 \\
\hline
\end{tabular}

Source: Own elaboration with Government of Information from the Mexico. Health Secretary. Epidemiological Surveillance System for Viral Respiratory Diseases as of August 1, 2020

Figure 2 Comorbidities identified in hospitalized patients with a positive result for (SARS-CoV-2) COVID-19, in the Totonacapan

Zone in Mexico

of August 1, 2020

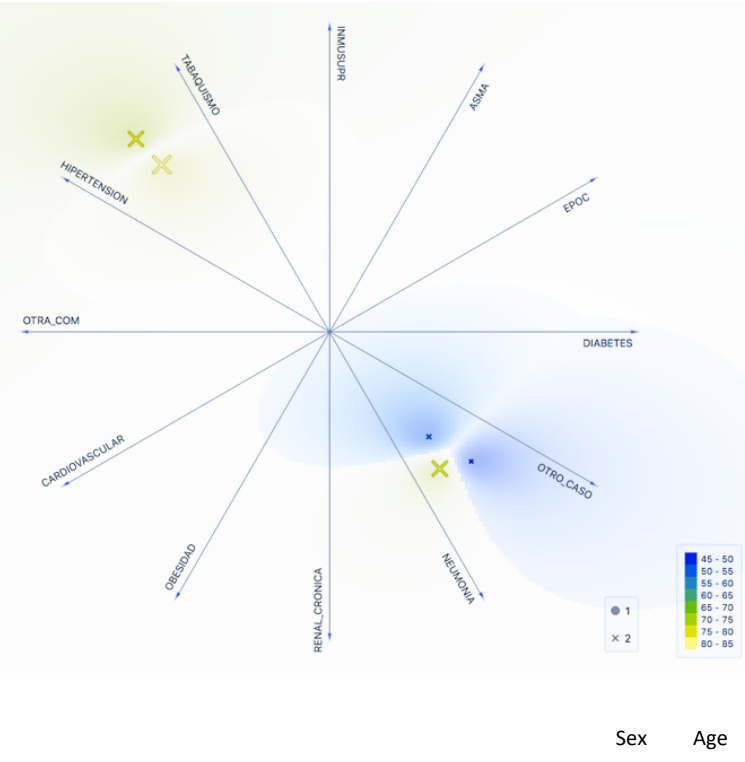

Sex $=1$ Women, Sex $=2$ Men

Source: Own elaboration with Government of Information from the Mexico. Health Secretary. Epidemiological Surveillance System for Viral Respiratory Diseases as of August 1, 2020 


\section{Map 1 Totonacapan area}

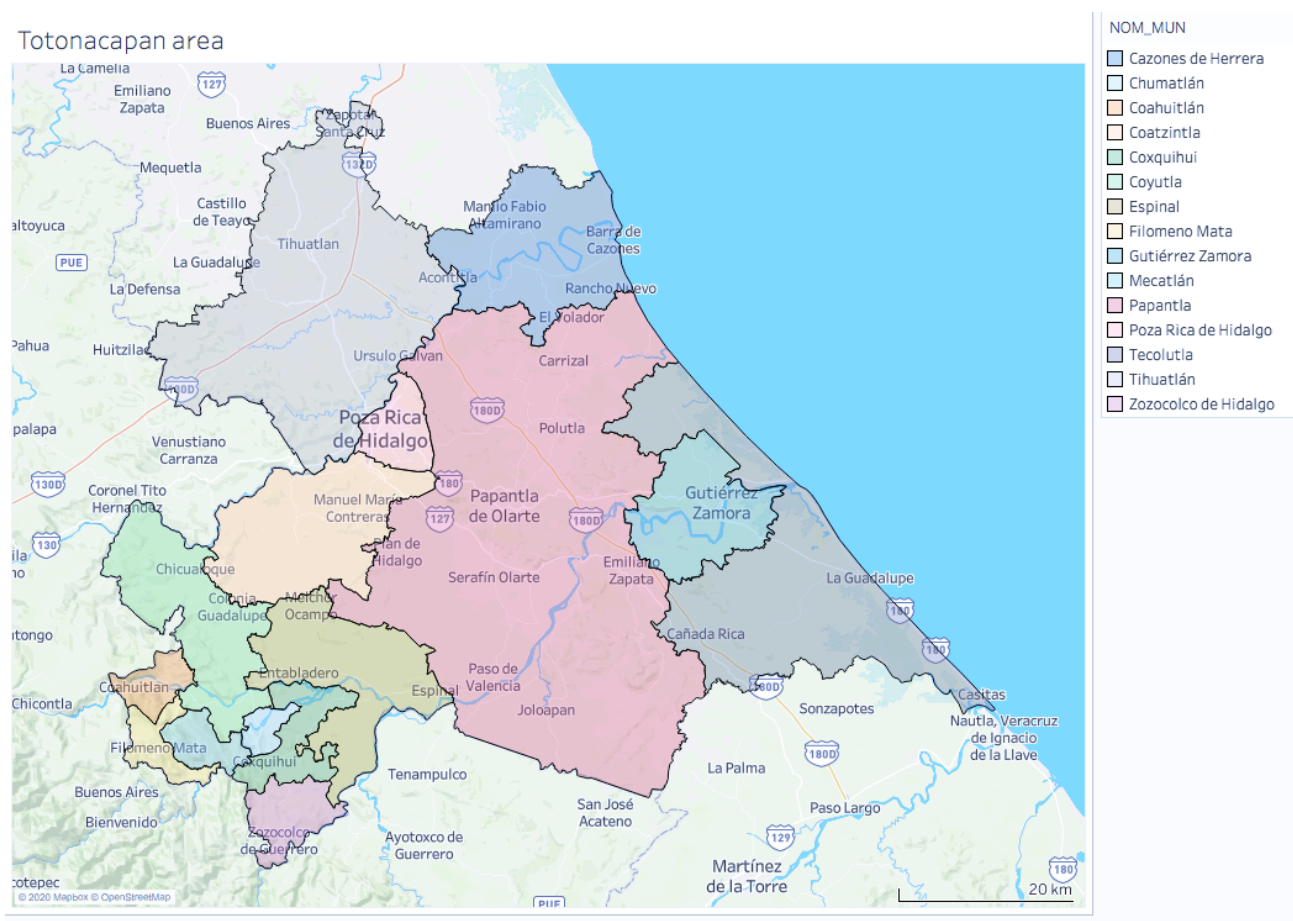

Source: Own elaboration.

With Catálogo de metadatos geográficos. Comisión Nacional para el Conocimiento y Uso de la Biodiversidad. División política municipal, 1:250000. 2010..

\section{Declaration of Competing Interest}

The authors declare that they have no known competing financial interests or personal relationships which have, or could be perceived to have, influenced the work reported in this article. 


\section{References}

[1] Demsar J, Curk T, Erjavec A, Gorup C, Hocevar T, Milutinovic M, Mozina M, Polajnar M, Toplak M, Staric A, Stajdohar M, Umek L, Zagar L, Zbontar J, Zitnik M, Zupan B (2013) Orange: Data Mining Toolbox in Python, Journal of Machine Learning Research 14(Aug): 2349-2353. https://dl.acm.org/doi/pdf/10.5555/2567709.2567736

[2] Government of Mexico. Health Secretary. Databases Covid-19 México. https://datos.gob.mx/busca/dataset/informacion-referente-a-casos-covid-19-en-mexico

[3] Software Orange Data Mining version 3.26.1 https://orange.biolab.si

[4] World Health Organization. (2020). Laboratory testing for coronavirus disease (COVID-19) in suspected human cases. Interim guidance. 19 March 2020. Recuperado de: https://www.who.int/publicationsdetail/laboratory-testing-for-2019-novel-coronavirus-in-suspected-human-cases-20200117

[5] Medel-Ramírez, Carlos and Medel-Lopez, Hilario, Data Mining for the Study of the Epidemic (SARSCoV-2) COVID-19: Algorithm for the Identification of Patients (SARS-CoV-2) COVID 19 in Mexico (June 3, 2020). Available at SSRN: https://ssrn.com/abstract=3619549 or http://dx.doi.org/10.2139/ssrn.3619549

[6] INEGI, (2010). Catálogo de metadatos geográficos. Comisión Nacional para el Conocimiento y Uso de la Biodiversidad. División política municipal, 1:250000. 2010. Palabras clave: 2010, Área Geoestadística, División, Límite, Municipios. Fecha de publicación: 04-07-2011, del metadato 20-07-2017. Available at : http://www.conabio.gob.mx/informacion/gis/

Reference to a dataset:

[7] Raw data can be retrieved from the Github repository https://github.com/CMedelR/dataCovid19/ 